\title{
BIORATIONAL MANAGEMENT OF FLEA BEETLES. Podagrica spp. (Coleoptera: Chrysomelidae) AND YIELD RESPONSE OF OKRA (Abelmoschus esculentus) (L.) Moench.) IN THE SOUTHERN GUINEA SAVANNA
}

\author{
Kabeh J.D. and Balogun K. \\ Crop Production and Protection Department, Faculty of Agriculture and Life Sciences, \\ Federal University Wukari, P.M.B. 1020, Wukari,Taraba State, Nigeria \\ Email: drkabeh4u@gmail.com Mobile: +234 8032511906
}

Cite this article:

Kabeh J.D., Balogun K. (2021), Biorational Management of Flea Beetles. Podagrica spp. (Coleoptera: Chrysomelidae) and yield response of Okra (Abelmoschus esculentus) (L.) Moench.) In the Southern Guinea Savanna. African Journal of Agriculture and Food Science 4(2), 1-12. DOI: 10.52589/AJAFS/F4SWLTNZ

\section{Manuscript History}

Received: 15 March 2021

Accepted: 13 April 2021

Published: 27 April 2021

Copyright $\odot 2020$ The Author(s). This is an Open Access article distributed under the terms of Creative Commons AttributionNonCommercial-

NoDerivatives 4.0 International (CC BY-NC-ND 4.0), which permits anyone to share, use, reproduce and redistribute in any medium, provided the original author and source are credited.
ABSTRACT: This experiments conducted in 2019, to evaluate yield response of Okra (Abelmoschus esculentus, (L.) Moench) to attractiveness of colour sticky traps in relation to other population sampling methods and bio-pesticidal effects of Aqueous delonix seed extract on the flea beetles, Podagrica Spp. (Coleoptera: Chrysomelidae) in the Southern Guinea Savanna zone of Nigeria. Experimental design uses six coloured sticky traps as treatments in Randomized Complete Block Design (RCBD) and replicated three times. The design for efficacies of Bio-pesticides also in $R C B D$ had four replications and five application rates, including a positive check and zero control as treatments. Yellow colour traps gave higher mean Podagrica Spp., catches but damage was higher in the white and purple traps, indicating other contributive factors affecting beetles feeding on Okra fruits. Higher precision was observed in hitting methods, when combined with colour reflectance. Yield of Okra fruits was optimum in all treatments, being higher in purple and least in white traps plants. Heavier fruits and least yield losses were in the least infected navy-blue treated plots. Agronomic performance was better in bio-pesticide treated Okra plants, but were not significant across different application rates with $57.30 \mathrm{~cm}^{2}$ peak leave area at $20 \mathrm{~g} / \mathrm{l}$, while mean fruit yield of 1007.00 was recorded at $15 \mathrm{~g} / \mathrm{l}$ Aqueous delonix seed application rate. Control had lowest mean fruit yield (780.00) with the highest fruits damage (11.33) per plot but heavier fruits recorded in the treated plants at $30 \mathrm{~g} / \mathrm{l}(66.75 \mathrm{~kg})$ over Cypermethrin (61.05kg). Pest population census showed significant $(P<0.05)$ decrease with increased application rates of the bio-pesticides. Hitting as sampling method was superior over sweep netting and was significantly different $(P<0.05)$ across the bio-pesticides application rates.

KEYWORDS: Okra, Flea Beetles, Colour Traps, Bio-Pesticides. 


\section{INTRODUCTION}

Okra (Abelmoschus esculentus L. Moench.) belongs to the family Malvaceae. It is an important vegetable crop of the tropical and subtropical regions of the world (Akinyele and Osekita, 2006). Because of high consumer demand and better prices, it is widely grown by farmers, throughout ecological zones of Nigeria. Nigeria ranks second in the world with 1.1 million tons of Okra produced from over 0.38million hectare of land (FAOSTAT, 2008; FAO, 2012). The crop is an erect herbaceous plant and one of the most important vegetable crops grown for its nutritional, medicinal and economic value (Alao, et al. 2011; Chopra et al. 2013). It is rich in vitamins, minerals, fibre and a source of calories $(4550 \mathrm{Kcal} / \mathrm{kg})$ for human consumption (Babatunde et al. 2007).

In Nigeria, Okra is grown mainly for its leaves, fibres and immature fruits used for consumption and commercial purpose (Kumar, et al. 2010; Varmudy 2011). The genus has about 150 known species; Okra is also called gumbo or lady's finger. The crop is widely cultivated either as rain fed or irrigated in all parts of Nigeria (Ndunguru and Rajabu, 2004). It occupies about 1.5 million hectares of the arable land in Nigeria alone (IFA, 1992). The world production of fresh okra fruits vegetables is estimated at 1.7 million t/year (Schippers, 2000). The cultivation of okra is mostly done by small scale farmers either as sole or intercropped with other vegetables, cereals or tubers (Udoh et al. 2005).

In spite of the economic importance of okra, its production is constrained by severe pests and disease attacks. Asare-Bediako et al (2014) rated the flea beetles amongst other pests as the most important. Feeding activities of Podagrica spp., causes severe damage, characterized by perforations and irregular holes on leaves leading to reduced photosynthetic area (Echezona and Offordile, 2011). The flea beetles $P$. sjostedti (Jacoby) and P. uniforma (Jacoby) comprises the two most common species, which coexist on the same plant, although each exhibit selective preferences between food plant species (Fasunwon and Banjo, 2010). In addition, Podagrica spp., transmits Okra mosaic virus, which causes significant yield losses (Obeng-Offori and Seckay, 2003; Ahmed et al. 2007; Fajinmi and Fajinmi, 2010). As high as 80 percent yield losses is attributable to these beetles, additionally okra is susceptible to at least 19 plant viruses causing yield losses of up to 90 percent (Alegbejo et al. 2008; Sayeed et al. 2014; Mobolade et al. 2014).

Conventional methods of protecting crops depend on use of synthetic chemical pesticides due to their swift action (Rissler and Quick-fix, 2016). However, Sani (2014) listed drawbacks of the synthetics, necessitating the needs for sustainable alternatives (bio-rational) being more reliable, environmentally friendly, cheap, readily available, while achieving much desired outcome (Fayinminnu and Shiro, 2014).

Colour attraction is an innate characteristic of insects. Yellow had proven more attractive to sucking insect's complex. Both visual and chemical stimuli play a major role in host plant location and identification by insects. Plants spectral quality (intensity) form the principle of stimuli for alignment of herbivorous insects on living plants (Echezona and Offordile, 2011). Colour preferences of crop pests incorporated on traps using attractive colours, provide opportunities for sound management of crop pests, thus lowering pesticides and residue problems on vegetables. Norris et al (2002) identified light traps, water trap, sticky traps attractiveness and various sensitivities were achieved, pests population monitoring of the flea beetles on Okra using colour preference is under researched, also effects of the sticky coloured 
traps on surrounding crops at the field levels demands further search (Ranamukhaarachchi and Wickramarachchi, 2007).

In pests monitoring and management, trapping provides the most convenient tools. Coloured sticky-traps are simple, low-cost methods for determining the relative abundance of insects and are used to monitor flying insect species on many crops (Lassio and Alma, 2004; Raja and Arivudainambi, 2004). Different coloured sticky-traps placed at a height of $157.5 \mathrm{~cm}$ are effective means of controlling these insects. Sticky traps have been widely used to monitor flying insects in many agro-ecosystems and a more preferable method for sucking insects. It has been used successfully against insect pests in ornamental plants, vegetables and potatoes in both fields and green-houses.

This method of population monitor had been documented on yellow sticky-traps for whiteflies, thrips and leafhoppers (Steiner et al. 1991). Height and sizes of traps were more important for adult flying insects. The sticky traps of different colours for B. tabaci population on Okra found $30 \mathrm{~cm}$ above ground level more effective against 60,90 or $120 \mathrm{~cm}$ height, also yellow sticky trap for leafhoppers recommends $25-75 \mathrm{~cm}$ above ground level in cotton fields (Uthamasamy et al. 1990).

Biopesticides offer desirable alternatives being nontoxic to beneficial insects and nonpersistent (Patel, et al. 2009). Bio-pesticides are effective even in small quantities and often decompose quickly resulting in lower exposures and less effects of pollution problems. The use of botanical products e.g Delonix seed extracts had been found promising and useful for pest control. It can greatly decrease the use of conventional pesticides, while achieving optimum yield in okra.

Many of the botanicals explored have broad spectrum activity, with the potentials as alternative to synthetics. Modi,et al. (2016) and Onunkun (2012) both reported the bio pesticidal potencies of Delonix to control the okra flea beetles Podagrica spp., however phytochemical and nonnutritive biologically active constituents and mechanism of action desire to be studied. The aqueous extracts contain allelopathic compounds including phenolic acids, alkaloids, quercetins and isoquercetin, Afzelin, Astragalin and flavonoid glycosides principles in protecting okra against the flea beetles, hence increase productivity of agricultural crops (Aina et al. 2009; Samar et al. 2012; Modi et al. 2016). This study aims to determine yield response of okra, on attractiveness of coloured sticky-traps, the efficacy of bio-pesticides and sampling methods on the incidence of flea beetles, Podagrica spp.

\section{MATERIALS AND METHODS}

These experiments were conducted at the Teaching and Research Farm, Federal University Wukari, Taraba State, Nigeria during the 2019 cropping season. To evaluate the yield response of okra (Abelmoschus esculentus (L.) Moench.) to attractiveness of coloured sticky-traps in relation to other population sampling methods, and bio-pesticidal effects of aqueous delonix seed extracts on okra flea beetles, Podagrica species, in the southern Guinea Savanna zone of Nigeria. Located between lat. $7.85^{\circ} \mathrm{N}$, Long. $9.78^{\circ} \mathrm{E}$ and $152 \mathrm{~m}$ above sea level, with annual rainfall, $1450 \mathrm{~mm}$, average daily temperatures, $24^{0}$ to $33^{\circ} \mathrm{C}$, during the rainy seasons; annual rel. humidity, $78 \%$ with soil physicochemical characteristics (Table 1). 
Table 1: Physico-Chemical Properties of the Teaching and Research Farm Federal University Wukari

\begin{tabular}{ll}
\hline Soil Properties & Values \\
\hline $\mathrm{pH}\left(\mathrm{H}_{2} \mathrm{O}, 1: 1\right)$ & 5.75 \\
Organic Carbon $(\%)$ & 1.36 \\
Organic Matter $(\%)$ & 2.35 \\
Total N (\%) & 0.98 \\
Available P(MgL-1) & 0.52 \\
Exchangeable K (Mol/Kg) & 1.6 \\
Exchangeable Na (Mol/kg) & 2.1 \\
Exchangeable Ca $(\mathrm{Mol} / \mathrm{kg})$ & 3.8 \\
Exchangeable $\mathrm{Mg}(\mathrm{Mol} / \mathrm{kg})$ & 1.8 \\
Exchangeable Acidity $(\mathrm{Mol} / \mathrm{kg})$ & 1.10 \\
TEB & 9.3 \\
CEC & 10.4 \\
Base Saturation $(\%)$ & 89.4 \\
Sand (g/kg) & 76.80 \\
Clay (g/kg) & 15.20 \\
Silt (g.kg) & 8.0 \\
Textural Class & Sandy soil \\
\hline
\end{tabular}

The experimental field was cleared, ploughed and harrowed with a tractor before the field lay out. A total area $14 \mathrm{~m} \times 27 \mathrm{~m}(0.0328 \mathrm{ha})$ were mapped out into experimental plots area $6 \mathrm{~m}^{2}$ with $1 \mathrm{~m}$ intra row spacing between plots and $2 \mathrm{~m}$ between replicates respectively. An improved treated okra seed Clemson spineless, early maturing and elongated cultivar obtained from Jubaili Agro-Chem shop in Wukari, was used for this trial. Two seeds per hill were sown manually by dibbling method at $45 \mathrm{~cm} \times 45 \mathrm{~cm}$ intra and inter-rows spacing respectively, average 1960 seeds were sown. Thinning and supply within the entire plot gave 35 plant stands per plot, average percentage stand count after supply was $75.20 \%$. Weeding was done manually using hoe at 3 and $6 \mathrm{WAS}$, while basal Urea fertilizer applied by side placement at 3WAS. Harvesting okra fruits was done three times a week over a period of one month. Six okra plant stands were tagged in each plot for data collection.

Experimental design for colour attractiveness utilizes six different coloured sticky boards, yellow, red, blue, white, purple and Navy-blue as the treatments in Randomized Complete Block Design (RCBD) and replicated three times. After 21 days of germination, colour traps were placed in the centre of each plot according to the treatments with the help of pegs stakes, no chemicals were applied in this trial.

Similarly, experimental design for efficacies of bio-pesticides in RCBD had four replications, five application rates $10 \mathrm{~g} / \mathrm{l}, 15 \mathrm{~g} / \mathrm{l}, 20 \mathrm{~g} / \mathrm{l}, 25 \mathrm{~g} / \mathrm{l}$ and $30 \mathrm{~g} / \mathrm{l}$ as the treatments, including a positive check, Cypermethrin $2 \mathrm{ml} / \mathrm{l}$, while only distilled water was applied on the control plots (zero treatment). These applications commenced at the flowering stage of plant growth.

Data were collected on agronomic and yield parameters, and lastly insect population census. All data collected were averaged and subjected to analysis of variance (ANOVA), using the 
statistical analysis system (SAS, 2006) while significant treatment means separated using Turkey HDS Test at $0.05 \%$ level of significance.

\section{RESULTS}

Agronomic parameters invariably show the likely yield responses of vegetative crops. The results of this experiment (Table 2.0) evidenced plant height to be uniform, with tallest plants in the red coloured trap plots $(46.35 \mathrm{~cm})$, while the shortest were in the yellow traps $(35.44 \mathrm{~cm})$, both however were not significantly different. The leaves area were larger in plants of plots bearing yellow traps $\left(47.35 \mathrm{~cm}^{2}\right)$ with the least surface areas $39.25 \mathrm{~cm}^{2}$ in plants of the plots with purple coloured traps, this also was not significantly different statistically.

Yield response in total marketable okra fruits harvested, was in plots with purple, navy-blue and red coloured sticky traps i.e 64.67, 63.00 and 59.00 respectively while least fruit yields were from plants in white colour-trap plots, still yield components across the treatments were not significantly different. Much higher damaged okra fruits were 11.96 and 10.93, recorded in plants bearing white and purple traps respectively. Heavier okra fruits per plots were 84.82, 69.75, 69.51 and 67.18 kilograms for navy-blue, yellow, red and purple treated plots respectively. Lighter fruits, $38.91 \mathrm{~kg}$, and $44.68 \mathrm{~kg}$ were recorded on plots with blue and white sticky traps.

Significantly higher, Podagrica spp., populations were observed in the plants carrying white sticky traps while navy-blue and purple treated plants have the lowest population of these beetles, 7.00 and 3.33 respectively. Combining the effects of the colour traps and sampling methods (Table 3.0), shows hitting methods significantly outperformed $(\mathrm{P}<0.05)$ other sampling methods. Highest population of 143.67 beetles was on the red, followed by 110.84 on yellow trap treated plots, lastly 101 beetles were recorded in the plots with white traps. Other methods, sweep netting and visual counts gave 70.67 and 66.17 beetles respectively and are significantly different $(\mathrm{P}<0.05)$ in their effects.

The results (table 4.0) gave slight improvement over the coloured sticky traps experiments, the agronomic parameters showed plant height uniformity across different application rates of the bio-pesticides and were not significantly different amongst treatments, same effects were recorded for the leaf area, being $57.30 \mathrm{~cm}^{2}$ and $57.06 \mathrm{~cm}^{2}$ for plants treated with $20 \mathrm{~g} / \mathrm{l}$ and $30 \mathrm{~g} / \mathrm{l}$ aqueous delonix seed extracts.

Peak okra fruit yields was 1007.00 in $15 \mathrm{~g} / \mathrm{l}$ treated plots, while the control plots recorded lower fruits (780.00) yields. Other application rates performed evenly with the synthetic (cypercal $\left.^{(R)} / 2 \mathrm{~m} / \mathrm{l}\right)$. More fruit damage (11.33) was in the control plots, while least was recorded on the cypermethrin treated plants. Heavier okra fruits per plot were in $30 \mathrm{~g} / \mathrm{l}(66.75 \mathrm{~kg})$ and cypermethrin treated plants $(61.05 \mathrm{~kg})$.

Podagrica spp., population census gave 28.38 and 39.13 beetles both from the control plot, and are significantly $(\mathrm{P}<0.05)$ higher than beetles population recorded in other application rates, with the least population 7.38 and 8.00 from the cypermethrin treated plots. Same consistency was observed with the different sampling methods (Table 5.0), as the hitting method was more efficient and had better precision over sweep netting and least sensitive visual counts, both however were significantly different $(\mathrm{P}<0.05)$ across the bio-pesticide application rates. 


\section{DISCUSSION}

The range within the electromagnetic energy spectrum perceptible to insects via ocular receptors includes the UV region between $350-650 \mathrm{~nm}$. Ranamukhaarachchi and Wickraamarachchi (2007) determined colour reflectance and insect attractions, characterized by intensity (density of pixels) for the basic colours. Peak reflectance varies in electromagnetic range $(500-580 \mathrm{~nm})$ for green, blue and yellow. Colour preference from the beetles populations recorded significant effects of beetle's catches (attractiveness) yellow traps gave higher mean Podagrica spp catches, but damage was most pronounced in the white and purple coloured traps, indicative that other factors may be contributive to beetles feeding on okra fruits. The number of beetles trapped by all colours was indicative of active roles in pest attractions, lowest beetle populations were trapped in navy-blue but trap effects do not differ significantly between colours.

Increase in population counts in relation to the sampling methods shows hitting adjudged to have higher precision, accounting for population build ups of Podagrica spp., in the red colour traps followed by yellow and white. Sweep nets and visual counts express higher precision in the white colour traps. There were precipitations during this period, average day time temperature ranged from $33-6^{0} \mathrm{C}$, relative humidity of $76-8 \%$ which accounts for population fluctuations recorded in this trial.

Feeding injuries occurs prominently on leaves, due to additive activities of other pest insects on okra fields. However, uninfested leaves and yield components data are the basis for our findings. Yield of okra fruits was optimum in all treated plots, being higher in purple colour trap plants and least in white. Similarly, fruits weight were heaviest in the navy-blue plots, same for damage recorded being least in relation to the beetles population distribution across different colour traps. Several studies on colour preference by pests favour white colour traps (Hoddle et al., 2002). If UV-reflectance is very high, flower dwelling insects are repelled from attractive colours, but vegetative feeding insects are not affected by UV reflective. Matteson and Terry (1992); Cho et al. (1995) reported high UV reflective white captured fewer pests in comparison to low UV reflective white, yellow and blue at $365 \mathrm{~nm}$.

All these findings on UV responses were on anthophilous (flower dwelling) pests. Studies on foliage dwelling pests gave significant variation in insects' responses. Vermon and Gillespie (1990) suggested most insect pests (vegetative dwelling) photoreceptors are tuned at $350-$ $360 \mathrm{~nm}, 440-450 \mathrm{~nm}$ and $540-570 \mathrm{~nm}$ in the UV, blue and yellow wavelengths respectively. Hence Podagrica spp., photoreceptors preferences to yellow and blue over navy-blue, purple and red.

Significantly, higher levels of infestations of Podagrica spp., is indicative probably on the attractiveness of sticky colour traps in mass trapping of these beetles. Results showed yellow, white and blue colours are the most attractive to these beetles, followed by purple and lastly navy-blue. Cumulative catches by hitting methods can be used to predict likely levels of infestation on yield losses in combustions with the most attractive colour to serve as tools for monitoring, mass trapping and protection of vegetable crops against pest damage to boost safer vegetable production.

The bio-pesticides aqueous delonix seed extract exhibited significant levels of insecticidal activity in effectively reducing flea beetle population and performed better than the untreated 
control. Furthermore, treated plants produced the highest yield. These results were confirmed by previous works of Adesina and Idoko (2013), Mobolade et al. (2014) and Benson (2017). The study also empirically evidenced comparative efficacies of the bio-pesticides to the synthetics Cypermethrin.

The bio-pesticides adequately protected the okra plants evidenced in better vegetative components performance, which invariably translates to improved yield components as corroborated by Mobolade et al. (2014). Furthermore, the protective effects of Delonix needs to be further established by research, since Aina et al. (2009), Samar et al. (2012) and Modi et al. (2016) identified the major phytochemical constituents, but mode and mechanism of action awaits further research.

\section{CONCLUSION}

Based on our findings, synergistic effects of yellow colour trappings and aqueous delonix seed extracts at $15 \mathrm{~g} / \mathrm{l}$ application rate can be recommended to mitigate destructive effects of okra flea beetles, Podagrica spp., as substitute to Cypermethrin contamination of okra commonly eaten raw, partially fried or boiled before consumption. Lastly, in case of population study, the hitting method significantly proves superior over other sampling methods, while efficient mass trapping alone is inadequate to maintain this pest beetle population below economic thresholds.

\section{REFERENCES}

Adesina, J.M and Idoko J.E. (2013). Field Evaluation of Insecticidal Activity of Chenopodium ambrosioides and Spondias mombin, crude extracts for control of okra flea beetles Podagrica unifoma Jacq. (Coleopteran: Chrysomelidae). Research. Journal of Agricultural Sc. 4(1):37- 39.

Ahmed, B.I., Adewumi, M.A., Ofuya, T.I and Folorunso, D.O. (2007) Effects of some aqueous medicinal plants extracts on Podagrica spp (Coleoptera : Chrysomelidae) infestation and yield of okra in a rain forest of Nigeria (Eds). Onibi, G. E., Agele S.O, Adekunle, V.A.J. and Olufayo, M.O. Proceedings of the $33^{\text {rd }}$ Annual conf. of school of Agriculture and Agric. Technology. Federal University of Technology, Akure, Nigeria. Pp. $48-51$.

Aina, S.A., Banjo, A. D., Lawal, O.A, Okoh, H.I, Aina, O.O and Dedeke G.A. (2009). The toxicity of extracts of Tetrapleura tetraptera (Aridan), Delonix regia (Flame of the forest) and Raphia vinifera (Raffia palm) on larvae of Anopheles gambiae. Academic Journal of Entomology._2(2):67-70.

Akinyele, B.O., and Osekita, O.S. (2006). Correlation and Path coefficient analyses of seed yield attributes in okra (Abelmoschus esculentus (L.) Moench.). African Journal of Biotechnology. 5:1330 - 1336.

Alao, F.O., Adebayo, T.A., Olaniran, O.A., and Akanbi, W.B. (2011). Preliminary evaluation of the insecticidal potentials of organic compost extracts against insect pest of okra (Abelmoschus esculentus L. Moench). Asian Journal of Plant Science and Research, 3:123- 130. 
Alegbejo, M., Ogunlana, M. and Banwo, O. (2008). Survey of incidence of okra mosaic virus in northern Nigeria and evidence for its transmission by beetles. Spanish Journal of Agricultural Research, 6: 408-411.

Asare-Bediako, E., Addo-Quaye, A.A. and Bi-kusi, A. (2014). Comparative efficacy of biopesticides in the management of Podagrica spp., and mosaic disease on okra (Abelmoschus esculentus (L.) Moench). American Journal of Experimental Agriculture. 4(8): $879-889$.

Babantude-Balo, R.O., Omotesho, O.A. and Sholotan, O.S. (2007). Socio-economic characteristics and Food Security status of farming households in Kwara state, North Central Nigeria. Pakistan Journal of Nutrition. 6(1): 16 - 20.

Benson, G.A.S. (2017). Efficacy of selected insecticides and Botanicals in the control of field insect pest of Okra (Abelmoschus esculentus (L.) Moench) in Akure, Nigeria. International Journal of Forestry and Horticulture, 3(4): 1-5.

Cho, K.J., Eckel, C.S., Walgenbatch, J.F., Kennedy, G.G. (1995). Comparison of coloured sticky traps for monitoring thrips populations (Thysanoptera: Thripidae) in staked tomato fields. Journal Entomological Science. 30:176 - 90.

Chopra, A. K., Srivastava, S. Kumar, V and Pathek, C. (2013). Agro-potentiality of distillery effluent on soil and agronomical characteristics of okra Abelmoschus esculentus (L.) Moench.). Environmental Monitoring and Assessment, 185:6635 - 6644.

Echezona, B.L. and Offordile, J.I. (2011). Responses of flea beetles (Podagrica spp) and okra plants (Abelmoschus esculentus L. Moench.) to different coloured polyethylene shades. International Journal of Pest Management 57(2): 161 - 168.

Fajinmi, A.A. and Fajinmi, O.B. (2010). Incidence of Okra mosaic virus at different growth stages of okra plants (Abelmoschus esculentus L. Moench.) under tropical conditions. Journal of General and Molecular virology. 2(1): 028 - 031.

FAO, (2012). Food and Agriculture Organization Production year book 2011, Rome. Retrieved from http://www.okra.fao.org

FAOSTAT, (2008). (http://fad.org). Accessed on 16th Nov. 2013.

Fasunwon, T.B., and Banjo, A. D. (2010). Seasonal population fluctuations of Podagrica species on okra plant (Abelmoschus esculentus L. Moench.). Research Journal of Agriculture and Biological Science. 6:283 - 288.

Fayinminnu, O. O. and Shiro, O.O. (2014). The pesticidal potentials of Alternanthera brasiliana (L.) O., Kuntz in solving pest problems in organic agriculture. Proceedings of the $4^{\text {th }}$ ISOFAR Scientific conference. Building organic bridges at the organic world congress, Istanbul, Turkey, pp 69.

Hoddle, M.S., Robbinson, L. and Morgan, D. (2002). Attraction of thrips (Thysapnotera: Thripadae and Aeolothripidae) to coloured sticky cards in California Avocado Orchards. Crop protection. 21:383- 8.

IFA, (1992). World Fertilizer Use Manual. Publication of International Fertilizer Industry Association, Paris, $311-315$ pp.

Kumar, S., Dagnoko, S., Haougui, A., Ratnadass, A., Pasternak, D., Kouame, C. (2010). Okra (Abelmoschus spp.). In West and Central Africa: Potential and Progress on its improvement African Journal of Agricultural Research, 5:35 - 90.

Lassio, F. and Alma, A. (2004). Dispersal patterns and chromatic response of Scaphoideus titanus Ball. (Homoptera:Cicadellidae) vector of the phytoplasma agents of grapevine. Flavescence doree. Agricultural Forest Entomology. 6:121 - 127. 
Matteson, N.I and Terry, L.A. (1992). Response to colour by male and female Frankliniella occidentalis during swarming and non-swarming behavior. Entomologia Experimentalis et applicata. 63: $187-201$.

Mobolade, A. J., Idoko, J.E. Rufus, J.A., and Eladuma, A.F. (2014). Control of flea beetles Podagrica spp. (Coleoptera: Chrysomelidae) Infestation on okra (Abelmoschus esculentus (L.) Moench) using piper guinensis seed extracts. Archives of Phytopathology and plant protection; 47 (19): 2332 - 2339.

Modi, A., Mishra, V. Bhatt, A. Mansoori, M.H., Gurnany, E. (2016). Delonix regia. Historic perspectives and Modern phytochemical and pharmacological researches. Chinese Journal of Natural Medicine; 14 (1): 31 - 39.

Ndunguru, J. and Rajabu, A.C. (2004). Effects of okra mosaic virus disease on the above ground morphological yield components of okra in Tanzania. Scientia Horticulturae; 99:225 - 235 .

Norris, R.F., Caswell-chen, E.P and Korgan. M., (2002). Concepts of Integrated Pest Management, Pretentic Hall, India. 376 - 7 pp.

Obeng-Offori, D and Sackey, J. (2003). Field evaluation of non-synthetic insecticides for the management of insect pests of okra (Abelmoschus esculentus (L.) Moench) in Ghana, Ethiopian Journal of Science. 26: 145-150.

Onunkun, O. (2012). Evaluation of aqueous extracts of five plants in the control of flea beetles on okra (Abelmoschus esculentus (L.) Moench). Journal of Biopesticides, 5:62 67.

Patel, P. S., Patel, G.M and Schukla, N.P. (2009). Evaluation of different modules for the management of the pest complex of okra. Pestology. 33 (1) : $31-37$.

Raja, K. M and Arivudainambi, S. (2004). Efficacy of sticky traps against bhendi leafhopper, Amrasca biguttula Ishida. Insect Environment. 10: 32 - 42.

Ranamukhaarachchi, S. L. and Wickramarachchi, K.S. (2007). Colour preference and Sticky traps for field management of thrips Ceratothripoides claratris (Shumsher). (Thysanoptera: Thripidae) in Tomato in Central Thailand. International Journal of Agriculture and Biology. 6: 839844.

Rissler, J. and Quick-fix, V.S. (2016). Sustainable Control Biotechnology and Pest Control. The Global Pesticide Campaigner. 20pp

Samar, S.A., Mohammed, A.D., Omaya, A.E. (2012).Phytochemical. Cytotoxic, Hepatoprotective and antioxidant properties of D. regia leaves extracts. Medicinal Chem. Research Journal. 22:4269-4277.

Sani, U.M (2014). Phytochemical Screening and antifeedant activity of the seed extracts of Parkia biglobosa against cowpea beans (Vigna unguiculata) storage pest (Callosobruchus maculatus.). International Journal of Innovative Research in Science, Engineering and Technology. 3(9): 15991 - 15995.

SAS, (2006). Institute Lac. SAS/STAT User's Guide: Version 6, Fourth Edition, Vol. 2, Carry, NC, SAS Institute Inc. 846pp

Sayeed, S.S., Rana, D., Krishna, G., Reddy, P.S. and Bhattacharya P.S., (2014). Association of Begomovirus with okra (Abelmoschus esculentus (L.) Moench) leaf curl virus disease in South India. SAJ. Biotechnology.1 (1): 1-4.

Schippers, R.R. (2000). African Indigenous Vegetable: An overview of the cultivated species. Chathan, U.K; Natural Resources Institute/ACPEU Technical Centre for Agricultural and Rural Cooperation, $103-113 p p$. 
Steiner, M.Y., Spohr, L.J, Barchia, I and Godwin, S. (1999). Rapid estimation of number of white flies (Hemiptera : Aleyrodidae) and Thrips ( Thysanoptera : Thripidae) on sticky traps. Australia Journal of Entomology, 38:367 - 373.

Udoh, D.J., Ndon, B.A., Asaquo, P.E and Ndueyo, N.U. (2005). Crop Production Technique for the tropics. Concept Publisher, Lagos, Nigeria, 223-247pp.

Uthamasamy, S., Srivasubramanian, P. and Thangaraju, D. (1990). Monitoring of whitefly, Bemisia tabaci on upland cotton. Gossypium hirsutum, Indian Journal of Agricultural Science, 60: $744-746$.

Varmudy, V. (2011). Marking survey need to boost okra exports. Department of Economics, Vive kanaanda College, Puttur, Karnataka, India. 36pp.

Vermon, R.S and Gillespie, D.R. (1990). Spectral responsiveness of Frankliniella occidentalis (Thysanoptera: Thripidae) determined by trap catches in green houses. Environmental Entomology. 19: 1229-1241. 
Table 2: Mean effects of Podagrica spp. affecting yield responses of Okra Abelmoschus esculentus (L.) Moench, in 2019 Cropping Season.

\begin{tabular}{l|lllllll}
\hline $\begin{array}{l}\text { Colour } \\
\text { traps }\end{array}$ & \multicolumn{2}{l}{ Agronomic Parameter } & \multicolumn{3}{l}{ Yield Parameter } & \multicolumn{3}{l}{ Podagrica Spp. Census } \\
& $\begin{array}{l}\text { Plant height } \\
(\mathrm{cm})\end{array}$ & $\begin{array}{l}\text { Leaves } \\
\text { Area }\left(\mathrm{cm}^{2}\right)\end{array}$ & $\begin{array}{l}\text { Marketable } \\
\text { fruits yield } \\
\text { per plot }\end{array}$ & $\begin{array}{l}\text { Damaged } \\
\text { fruits per } \\
\text { plot }\end{array}$ & $\begin{array}{l}\text { Fruit } \\
\text { weight } \\
\text { per plot } \\
(\mathrm{kg})\end{array}$ & $\begin{array}{l}\text { P. } \\
\text { sjosted } \\
\text { ti }\end{array}$ & $\begin{array}{l}\text { uniforma } \\
\text { unde }\end{array}$ \\
\hline White & 41.20 & 42.67 & 38.00 & 11.96 & 44.68 & $8.00^{\mathrm{ab}}$ & $9.00^{\mathrm{b}}$ \\
Yellow & 35.44 & 47.35 & 45.00 & 5.98 & 69.75 & $13.33^{\mathrm{a}}$ & $20.33^{\mathrm{a}}$ \\
Red & 46.87 & 41.19 & 59.00 & 6.44 & 69.51 & $6.33^{\mathrm{b}}$ & $7.67^{\mathrm{b}}$ \\
Blue & 43.67 & 41.35 & 48.67 & 6.12 & 38.91 & $4.33^{\mathrm{b}}$ & $10.33^{\mathrm{b}}$ \\
Purple & 44.87 & 39.25 & 64.67 & 10.93 & 67.18 & $3.33^{\mathrm{b}}$ & $8.67^{\mathrm{b}}$ \\
Navy- & 45.43 & 39.42 & 63.00 & 5.22 & 84.82 & $3.67^{\mathrm{b}}$ & $7.00^{\mathrm{b}}$ \\
blue & & & & & & & \\
SEM & $6.03^{\mathrm{NS}}$ & $5.16^{\mathrm{NS}}$ & $8.91^{\mathrm{NS}}$ & $2.81^{\mathrm{NS}}$ & $12.36^{\mathrm{NS}}$ & $1.28^{*}$ & $1.82^{*}$ \\
CV & 24.35 & 21.32 & 28.52 & 14.33 & 34.21 & 34.21 & 29.95 \\
\hline
\end{tabular}

Note: Means on some rows bearing different superscripts differ significantly $(P<0.05)$ according to Tukey's HSD at 5\% level of significance.

Table 3: Mean Population Densities of Podagrica spp. per coloured sticky-trap and sampling methods on Okra A. esculentus (L.) Moench., in 2019 Cropping Season

\begin{tabular}{l|lll}
\hline & \multicolumn{3}{c}{ Sampling methods } \\
Colour Traps & Sweep netting & Visual counts & Hitting \\
\hline White & $70.67^{\text {bcd }}$ & $66.17^{\text {bcd }}$ & $101.84^{\mathrm{ab}}$ \\
Yellow & $53.34^{\text {bcd }}$ & $33.00^{\mathrm{d}}$ & $110.84^{\mathrm{ab}}$ \\
Red & $48.00^{\mathrm{bcd}}$ & $29.67^{\mathrm{d}}$ & $143.67^{\mathrm{a}}$ \\
Blue & $44.17^{\mathrm{bcd}}$ & $28.50^{\mathrm{d}}$ & $85.00^{\mathrm{bcd}}$ \\
Purple & $41.50^{\mathrm{cd}}$ & $27.34^{\mathrm{d}}$ & $92.67^{\mathrm{ab}}$ \\
Navy-blue & $50.34^{\mathrm{bcd}}$ & $3.17^{\mathrm{e}}$ & $92.17^{\mathrm{ab}}$ \\
SEM & 7.43 & & \\
CV & 17.21 & & \\
\hline
\end{tabular}

Note: Means on the same row bearing different superscripts differ significantly $(P<0.05)$ according to Tukey's HSD at 5\% level of significance. 
Table 4.0: Mean effects of Aq. delonix seed extracts on Podagrica spp., effecting yield responses of Okra A. esculentus (L.) Moench., in 2019 cropping season.

\begin{tabular}{|c|c|c|c|c|c|c|c|}
\hline \multirow{2}{*}{$\begin{array}{l}\text { Aq. delonix } \\
\text { seed extract } \\
(\mathrm{g} / \mathrm{l})\end{array}$} & \multicolumn{2}{|c|}{$\begin{array}{l}\text { Agronomic } \\
\text { Parameters }\end{array}$} & \multicolumn{2}{|c|}{ Yield Parameters } & \multicolumn{3}{|c|}{ Podagrica Spp. Census } \\
\hline & $\begin{array}{l}\text { Plant } \\
\text { height } \\
(\mathrm{cm})\end{array}$ & $\begin{array}{l}\text { Leaves } \\
\text { Area } \\
(\mathrm{cm} 2)\end{array}$ & $\begin{array}{l}\text { Marketable } \\
\text { fruits yield } \\
\text { per plot }\end{array}$ & $\begin{array}{l}\text { Damaged } \\
\text { fruits per } \\
\text { plot }\end{array}$ & $\begin{array}{l}\text { Fruit } \\
\text { weight } \\
\text { per plot } \\
(\mathrm{kg})\end{array}$ & $\begin{array}{l}P . \\
\text { Sjostedti }\end{array}$ & $\begin{array}{l}\mathrm{P} . \\
\text { Uniforma }\end{array}$ \\
\hline Control & 54.10 & 55.3 & 78.30 & 11.33 & 45.78 & $29.13^{\mathrm{a}}$ & $28.38^{a}$ \\
\hline $10 \mathrm{~g} / 1$ & 53.46 & 53.70 & 815.00 & 9.77 & 42.85 & $27.63^{\mathrm{ab}}$ & $24.50^{\mathrm{abc}}$ \\
\hline $15 \mathrm{~g} / 1$ & 49.96 & 53.70 & 1007.00 & 7.72 & 54.83 & $20.13^{\mathrm{abc}}$ & $14.63^{\mathrm{cd}}$ \\
\hline $20 \mathrm{~g} / 1$ & 54.20 & 57.30 & 903.80 & 8.11 & 58.05 & $16.75^{\mathrm{cd}}$ & $16.25^{\mathrm{bcd}}$ \\
\hline $25 \mathrm{~g} / 1$ & 52.56 & 52.87 & 919.50 & 6.74 & 51.95 & $19.00^{\mathrm{bc}}$ & $18.00^{\mathrm{bc}}$ \\
\hline $30 \mathrm{~g} / 1$ & 52.40 & 57.06 & 970.30 & 6.44 & 66.75 & $11.63^{\mathrm{cd}}$ & $7.75^{\mathrm{d}}$ \\
\hline $\begin{array}{l}\text { Cypercal }^{\circledR} \\
(2 \mathrm{ml} / \mathrm{l})\end{array}$ & 51.30 & 55.40 & 929.80 & 6.37 & 61.05 & $8.00^{\mathrm{d}}$ & $7.38^{\mathrm{d}}$ \\
\hline SEM & 2.8 & 1.86 & 98.40 & 1.34 & 92.93 & 2.18 & 2.09 \\
\hline $\mathrm{CV}$ & 21.36 & 13.52 & 21.78 & 26.50 & 34.09 & 32.69 & 35.36 \\
\hline
\end{tabular}

Note: Means on the same column bearing the same superscript are not significantly different $(P>0.05)$ according to Turkey HSD at $5 \%$ level of significance.

Table 5.0: Mean population of Podagrica spp. Per Aq. delonix seed extracts and sampling methods on Okra, A. esculentus (L.) Moench, in the 2019 cropping season.

\begin{tabular}{|c|c|c|c|}
\hline $\begin{array}{l}\text { Aq. delonix seed } \\
\text { extracts }(g / 1)\end{array}$ & $\begin{array}{l}\quad \text { Sampling } \\
\text { methods } \\
\text { Sweep netting }\end{array}$ & Visual counts & Hitting \\
\hline Control & $51.50^{\mathrm{ab}}$ & $34.50^{b c}$ & $63.50^{\mathrm{ab}}$ \\
\hline $10 \mathrm{~g} / \mathrm{l}$ & $40.00^{\mathrm{b}}$ & $29.50^{\text {cd }}$ & $64.25^{\mathrm{a}}$ \\
\hline $15 \mathrm{~g} / 1$ & $35.25^{\mathrm{bc}}$ & $22.75^{\text {de }}$ & $34.25^{\mathrm{bc}}$ \\
\hline $20 \mathrm{~g} / 1$ & $31.75^{\mathrm{bcd}}$ & $22.75^{\mathrm{de}}$ & $34.25^{\mathrm{bc}}$ \\
\hline $25 \mathrm{~g} / 1$ & $33.75^{\mathrm{cd}}$ & $17.75^{\mathrm{de}}$ & $39.75^{\mathrm{abc}}$ \\
\hline $30 \mathrm{~g} / 1$ & $13.00^{\mathrm{e}}$ & $17.50^{\mathrm{de}}$ & $25.75^{\mathrm{cd}}$ \\
\hline Cypercal ${ }^{\circledR}(2 \mathrm{~m} / 1)$ & $14.50^{\mathrm{de}}$ & $17.50^{\mathrm{de}}$ & $16.25^{\mathrm{de}}$ \\
\hline SEM & 3.09 & & \\
\hline $\mathrm{CV}$ & 23.91 & & \\
\hline
\end{tabular}

Note: Means on the same row bearing different superscripts differ significantly $(P<0.05)$ according to Turkey's HSD at 5\% level of significance. 